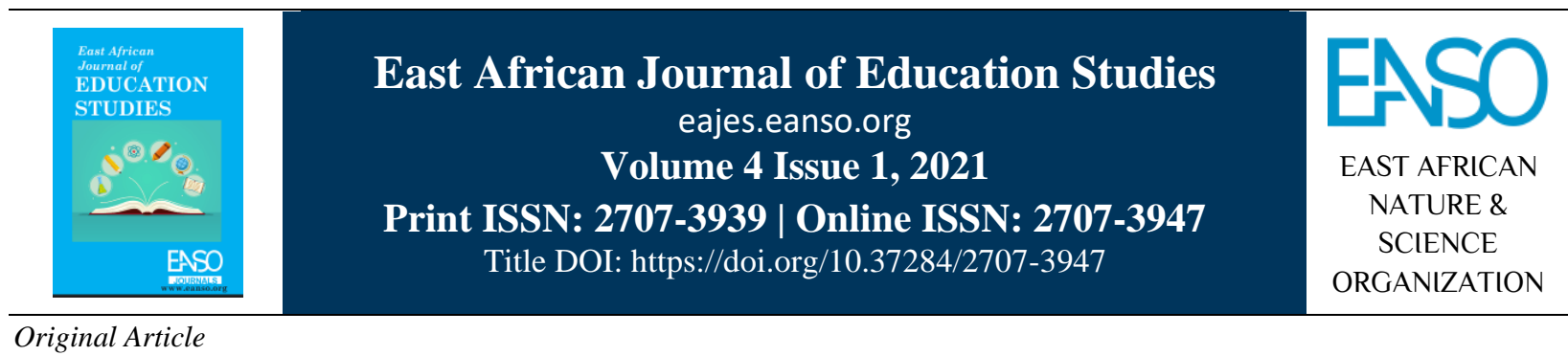

\title{
Status of Digital Literacy Programme in Public Primary Schools in Homa Bay County, Kenya.
}

\author{
Dr. Ouma Omito, PhD*1 \\ ${ }^{1}$ Bomet University College, P. O. Box 701-20400, Bomet, Kenya. \\ * Author for Correspondence Email: oumaomito@buc.ac.ke.
}

Article DOI: https://doi.org/10.37284/eajes.4.1.443

\section{Date Published: ABSTRACT}

19 October 2021 The study assessed the readiness levels of public primary schools in Homa Bay County for the integration of digital teaching and learning. A population of 556

Keywords: teachers in public primary schools that had already received Digital Literacy Programme (DLP) devices for teaching and learning were used whereby a Digital, sample size of 56 teachers was reached at. 12 teachers were also interviewed. Literacy, A reliability coefficient of 0.962 was obtained. Interview questions that were Laptop Computers, unclear were either modified or removed. Content validity confirmed the Integration. appropriateness of the content and the research tools used during the study. Findings from observation checklists were analysed quantitatively by use of descriptive statistics. Data from interviews were transcribed, coded and grouped into major themes and then reported. The study found that majority of the sample schools $(55.4 \%)$ had not started teaching using DLP. The study also showed that teachers who were practicing using the DLP devices were more proficient in computer use compared to those who either kept or feared using such devices for educational activities. The study concluded that the government's initiative of digitalizing schools was a noble idea that needed to be embraced by all sectors of the economy.

\section{APA CITATION}

Omito, O. (2021). Status of Digital Literacy Programme in Public Primary Schools in Homa Bay County, Kenya. East African Journal of Education Studies, 4(1), 37-47. https://doi.org/10.37284/eajes.4.1.443.

\section{CHICAgO CITATION}

Omito, Ouma. 2021. "Status of Digital Literacy Programme in Public Primary Schools in Homa Bay County, Kenya". East African Journal of Education Studies 4 (1), 37-47. https://doi.org/10.37284/eajes.4.1.443.

\section{HARVARD CITATION}

Omito, O. (2021) "Status of Digital Literacy Programme in Public Primary Schools in Homa Bay County, Kenya", East African Journal of Education Studies, 4(1), pp. 37-47. doi: 10.37284/eajes.4.1.443. 
IEEE CITATION

O. Omito, "Status of Digital Literacy Programme in Public Primary Schools in Homa Bay County, Kenya”, EAJES, vol.4, no. 1, pp. 37-47, Oct. 2021.

\section{MLA CITATION}

Omito, Ouma. "Status of Digital Literacy Programme in Public Primary Schools in Homa Bay County, Kenya". East African Journal of Education Studies, Vol. 3, no. 1, Oct. 2021, pp. 37-47, doi:10.37284/eajes.4.1.443.

\section{INTRODUCTION}

\section{Background to the Study}

The introduction of a structured technology plan in Kenyan schools is traced back to 2006 when Information Communication and Technology (ICT) framework was launched. The proposal was on the ICT framework was generation usage and integration of ICT in educational institutions in Kenya (Kenya. Moe, 2006). Before the launch of ICT policy in 2006, Kenya had in place computer laboratories with desktop computers and more particularly in post primary learning institution with no implementation plan policy in place. A good example is the proposal in the ICT policy framework that outlined the one desktop computer to be shared out by a maximum of fifteen learners in a learning institution (Kenya. Moe, 2006, p. 1).

The One Laptop Per Child program under this study was a proposal of the Kenyan Government immediately after the 2013 general elections in Kenya. It was part of the Jubilee Government Manifesto to the people of Kenya during the political campaigns of 2012 a head of the general elections. Immediately after the Kenyan President Uhuru Kenyatta was voted into power, the journey to One Laptop Computer per Child in class one in all public schools in Kenya began. The laptop computer program was then slated to kick off in January 2014 (Sharples \& Moldies, 2014).

Records showed that by 2015, Kenya had 22,175 public primary schools (Republic of Kenya, 2015). It the children of these public primary schools who were intended to be the beneficiaries of the roll out and integration of ICT programs. To show the government commitment on this, a total of 62,500 teachers were trained by August 2015 (Republic of Kenya, 2015). The training program selected just 3 teachers from each school to attend a 5-day training, after which the trained teachers were expected to return to their schools to train their colleagues who were left in schools.

According to ICT Authority in Homa Bay County where the study was conducted, a number of things had been put in place in public primary schools in readiness for the launch of DLP. The statistics obtained from this government body indicated that majority of the schools at least had 3 DLP trained teachers and electricity had been connected to $85.8 \%$ of the schools in the county. As well a total of 551 schools in the county had already been provided with DLP devices in 2016 (Kenya. ICTAL, 2016).

\section{Statement of the Problem}

In line with the Government of Kenya's report, the entire 22,175 public primary schools in Kenya were set to benefit from DLP and that 62,500 primary teachers in public primary schools in the whole country had already been trained for DLP by 2015 . Power installation and DLP storage cabinets had also been scaled up in such schools. Document analysis from the ICT Authority revealed that a total of $551(63.7 \%)$ schools had received DLP devices in Homa Bay County at the time of this study. Therefore, everything looked set for the launch and integration of ICT in public primary schools in Kenya. However, these were theoretical reports that needed confirmation on the ground. The question was: Did Homa Bay County have DLP devices and trained teachers in its public primary schools?

\section{Purpose of the Study}

The purpose of this study was to investigate the integration of Digital Literacy Programme (DLP) in public primary schools in Homa Bay County, Kenya. 


\section{Objectives of the Study}

The objectives of the study were:

- To investigate the availability of DLP devices in public primary schools in Homa Bay County

- To assess the level of integration of DLP devices in public primary schools in Homa Bay County

\section{LITERATURE REVIEW}

Technologies used in learning institutions are varied and are collectively known as Information Communication and Technology (ICT). ICT has been regarded as a device or any application(s) that includes but not limited radio, television, cellular phones, satellite systems, computers etc. and their peripheral devices. The peripheral devices are those devices/ gadgets that connect a communicating system such as a desktop computer to add functionality. Every computer has the processor which performs logic, does memory access and computation. According to McLoughlin (2011), peripheral devices are usually classified according to their functions:

- Input devices such as keyboards, mice, bar-code scanners and digitizers.

- Output devices like printers, plotters and displays.

- Storage devices, which include floppy and hard disks, optical disks and magnetic tape drives.

- Multi-media devices and others

ICTs are proving to be more powerful and have the ability to integrate multimedia into simple educational applications (Reddy \& Majolica, 2002). The acronym ICT can also take a plural form (technologies) where it is understood to entail the specific devices or processes which collectively make up the "Technology" (Lloyd, 2005). The ICT devices with processors are classified as computers but may take different shapes, forms or designs. We have mobile phones that operate like computers. We also have laptops and tablets as forms of computers. More specifically, laptop computers and tablets are personal computers that can easily be carried and used in a variety of locations. They are designed to have all functionality of desktop computers, which means they can generally run the same software and open the same types of files as desktop computers. With these qualities in place, they have largely been proposed by a number of educational institutions as effective devices for online education (Gökmen et al., 2018).

In education, computers have for a long time been used for creating, accessing, gathering, manipulating and reporting information (Lloyd, 2005). Such important education roles that are necessary to teaching and learning are taken care of by the computer hardware and software applications such as Microsoft Office, connectivity to the internet by local networking infrastructure, videoconferencing among others (Reddy \& Majolica, 2002). ICT is, therefore, seen as a global revolution, that is, the scope of the digital world that is comparable to that of the physical world. That is, from online gaming and online dating to e-learning and e-business. At the same time, engagement in the digital world is phenomenal. The growth of elearning is sporadic and dramatic to the extent that it should not be ignored in a learning environment (Lim et al., 2013).

A number of countries in the world have been in the trial of digital learning or the implementation phase. The society, therefore, is expecting its education systems to aptly respond by adopting tailored technology-based ICT education such as the use of laptop computers for teaching and learning (Mike, 2011). In Africa, One Laptop Per Child (OLPC) project was launched in Ghana in 2005 by a nonprofit organization that was seeking to provide laptop computers to children in poorer and more remote areas of the world (Hennessy, et al., 2010). And as such, the potentials of ICTs in increasing access and improving relevance and quality of education in developing countries are seen to be on the rise (Mike, 2011).

Eastern Africa was not left out in closing the digital gap. In 2014, Rwanda was probably the first African country to attain the recommended ratio of one computer against fifteen students in primary schools. Over 200,000 laptop computers were distributed to 410 primary schools which gave access to $20 \%$ of students in primary 4,5 , and 6 in Rwanda. Rwanda also engaged in the training of 
over 10,000 head teachers and classroom teachers for the successful uptake of laptop computers (Republic of Rwanda, 2015). In Kenya and more particular Homa Bay County, no much had been realized in terms of ICT integration. The available computer laboratories in this county were largely not equipped with less proper attention paid to teaching and learning using technology. However, a study conducted in this county in 2020 positively emphasized the need to incorporate ICT in both the teaching and management of schools (Gilbert et al., 2020).

\section{METHODOLOGY}

\section{Research Design}

The design adopted for this study was a crosssectional survey. Concurrent data triangulation was used to show the connections/divergence of both quantitative and qualitative data. The research design for this study was a concurrent triangulation cross-sectional survey (Creswell, 2011, p. 213). Survey designs have proven useful for data collection tools such as questionnaires or structured interviews especially for generalizing findings obtained from a sample in a given population (Cresswell, 2011, p. 12). Tolmie et al. (2011) added that a cross-sectional survey is suited for examining variables in different groups that are similar in nearly all other characteristics.

\section{Population of the Study}

The study was confined to 551 public primary schools in Homa Bay County that had already received or already had been supplied with DLP devices in Homa Bay County. To ensure adequate coverage of the county, sample schools in all the six sub-counties of Homa Bay were involved in the study: Mbita, Homa Bay, Rachuonyo North, Rachuonyo South, Suba, and Ndhiwa.

\section{Sampling Procedure for Teachers in Schools with DLP Devices}

Gay and Diehl (1992) observed that the number of respondents acceptable for any study is dependent upon the type of research involved. They added that the type of research design adopted is no exception to this rule whether it is descriptive, correlational, or experimental. In this case, descriptive research is reliable when the sample size is $10 \%$ of the population especially when the study population is big. However, in cases where the research population is smaller, $20 \%$ of the study population can be used. In this particular case, $10 \%$ of the study population of 551 public primary schools was used and considered appropriate for representation. The $10 \%$ of 551 public primary schools gave a sample size of 56 schools. The researcher targeted one DLP teacher in each of the 551 schools. Hence, the sample size for the schools was the same as the sample size for DLP teachers, that is, 56 DLP teachers in Homa Bay County schools.

Table 1: Sample size of teachers in schools with DLP devices

\begin{tabular}{lll}
\hline Sub County & Population & Sample size \\
\hline Homa Bay & 111 & 11 \\
Mbita & 97 & 10 \\
Ndhiwa & 98 & 10 \\
Rachuonyo North & 109 & 11 \\
Rachuonyo South & 48 & 5 \\
Suba & 88 & 9 \\
Total & $\mathbf{5 5 1}$ & $\mathbf{5 6}$ \\
\hline
\end{tabular}

\section{Research Instruments}

The researcher developed two sets of research tools. These were observation checklist that was used by the researcher to assess the teachers' computer capacity in schools which had received DLP devices and interview schedules that generated information from randomly selected teachers purposefully for concurrent data triangulation. 


\section{Observation Checklist for Teachers in Schools with DLP Devices}

Teachers needed practical experience with laptop computers and tablets before and during the integration process. An observation checklist was used for direct observation whereby teachers in the sampled schools with DLP devices were requested to perform specific ICT skills using laptop computers practically in the presence of the observer who was the researcher. The used observation schedule for practical assessment of ICT skills worked in two folds. In the first scenario, a case where a teacher was practically assessed on ICT skills in schools that had received DLP devices and had not started teaching and learning using these devices because of one reason or the other. The second scenario was whereby ICT skills were accessed on teachers who were already teaching using such devices in class. one was a case whereby DLP devices had been received by a school and no learning with such devices was on in such schools. In sampled schools that had no DLP devices in schools in contradiction to the reports available at the supplier of such devices, ICT Authority of Kenya, part of checklist schedule directed the researcher to note down the reasons or statements on the same from the school head teacher.

\section{Reliability and Validity of Observation Checklist on Teachers' Computer Capacity in Schools with DLP Devices}

The observation checklist had a reliability coefficient of 0.962 . This followed the thorough computation using the Internal Consistency Reliability Test. Based on this result; the instrument was strong and very reliable for data collection. The reliability of the interview schedule was realized by the removal of questions that were ambiguous to the respondents during the piloting stage. The aim of such removal was to enable the instrument to gather accurate and dependable information. Content validity was checked to confirm that the questions asked in both the interview and observation checklist captured the required information for the study.

\section{Data Collection Procedures}

National Commission for Science and Technology Innovation (NACOSTI) issued the research permit. The NACOSTI permit was forwarded by both the Ministry of Education in Kenya and the County Commissioners office as a matter of introduction of the research participants to schools and to ensure the safety of the participants and respondents during the study. The activity that followed was thorough induction/training of research assistants who were then posted to different sub-counties of Homa Bay. Both the researcher and research assistants participated in data collections during piloting and the main study. Data cleaning followed immediately whereby the checklist was thoroughly monitored to take care of areas that were not observed. The data collection tools were interview schedules and observation checklists. The observed data were then keyed in for data analysis using SPSS. The collected qualitative data was prepared for analysis by transcription and coding.

\section{Data Analysis}

Both quantitative and qualitative data were generated for analysis. Quantitative data from observation schedules was analysed by use of descriptive statistics such as tables, percentages, and average mean scores. Statistical Package for Social Sciences (SPSS) was used. Data obtained from the interview schedule was manually transcribed, coded, and organized into major themes. This was after the recording of the interview session using a digital camera.

\section{Response Rate}

There was $100 \%$ response rate from the 12 teachers who were interviewed and 56 administered observation checklists.

\section{RESEARCH FINDINGS}

\section{Schools currently Teaching and Learning with DLP Devices}

To ensure accuracy of information especially on the schools that were actively teaching and learning with laptops, the researcher visited all the sampled 
East African Journal of Education Studies, Volume 4, Issue 1, 2021

Article DOI: https://doi.org/10.37284/eajes.4.1.443

schools and recorded the following information as

shown in Table 2 below.

Table 2: Schools that were teaching and learning with DLP devices

\begin{tabular}{lll}
\hline Responses & Number of schools & Percent \\
\hline Yes & 25 & 44.6 \\
No & 31 & 55.4 \\
Total & $\mathbf{5 6}$ & $\mathbf{1 0 0 . 0}$ \\
\hline
\end{tabular}

In line with the research findings, all the 56 sampled schools had received DLP devices but only $25(44.6 \%)$ schools were on with the teaching and learning using laptop computers. The other $31(55.4 \%)$ schools which formed the majority, had received DLP devices in their schools but were still kept under lock and key in their respective schools.

\section{Reasons for not Teaching and Learning using DLP Devices}

Based on the findings displayed in Table 3, a total of 31 schools which was the majority of schools had received DLP devices but actually had not started teaching and learning using such devices. The schools posted a number of reasons for such failures as shown in table 3 below.

Table 3: Reasons for not teaching and learning using DLP devices in schools with DLP devices

\begin{tabular}{lll}
\hline Reason & Frequency & Percent \\
\hline Lack of electric power & 10 & 32.4 \\
Insecurity in schools & 2 & 6.5 \\
Inadequate computer training & 11 & 35.5 \\
Lack of DLP classrooms & 2 & 6.5 \\
Transfer of DLP teachers & 1 & 3.0 \\
No response from the respondents & 5 & 16.1 \\
Total & $\mathbf{3 1}$ & $\mathbf{1 0 0 . 0}$ \\
\hline
\end{tabular}

Different schools cited different reasons why they were not teaching using DLP devices. 10 (32.1\%) schools cited lack of power connection, $2(6.5 \%)$ of the sampled schools, on the other hand, were scared of insecurity in public primary schools $11(35.5 \%)$ of these schools held the position that they had no properly trained DLP teachers for the project, $2(6.5 \% 0$ schools cited lack of isolated DLP classrooms, $1(3.0 \%)$ of the schools blamed the government for lack of policy on transfer of DLP trained teachers and lastly the remaining $5(16.1 \%)$ schools had no good reasons as to why they had not started teaching and learning using DLP devices in their schools.

\section{Repair of DLP Devices}

The DLP devices were not manufactured in schools but external suppliers of the same from Moi University and Jomo Kenyatta University of Science and Technology contracted to supply these schools with the devices. These supplies only left their contacts in schools with no proper guidelines on repairs and maintenance. The respondents were requested to indicate whom they could rely on in case of repairs and maintenance. 
East African Journal of Education Studies, Volume 4, Issue 1, 2021

Article DOI: https://doi.org/10.37284/eajes.4.1.443

Table 4: Repair of DLP devices

\begin{tabular}{lll}
\hline Who to repair & Frequency & Percent \\
\hline School & 4 & 7.1 \\
ICT Authority & 19 & 33.9 \\
MOEST & 11 & 19.6 \\
Not known & 22 & 39.3 \\
Total & $\mathbf{5 6}$ & $\mathbf{1 0 0 . 0}$ \\
\hline
\end{tabular}

Every piece of equipment whether digital or manual needs to be serviced and repaired to be in good working condition. These are precautions that needed to be taken before the devices were delivered to schools. The study showed that 4(7.1\%) of the schools believed that it was the responsibility of each and every school to repair its own digital devices. Some 19 (33.9\%) schools felt that it was the responsibility of the ICT Authority of Kenya. The study further revealed that 11(19.6\%) sampled schools were of the opinion that it was the responsibility of the Ministry of Education, whose docket hosts all public primary schools in Kenya, was to take charge of the maintenance of DLP devices. The remaining (39.3\%) sample schools that were the majority had no idea at all on where and whom to see in case of any breakages or malfunctions of the digital devices in their schools.

\section{Teachers' Computer Capacity in Schools with DLP Devices}

The teachers' actual/ practical manipulation of computers on the required ICT skills was observed and the mean generated on the teachers' competence on such operations on a 5-point Likert scale of Not at all $=1$, Not so well $=2$, Okay $=3$, well $=4$, Very well $=5$ and results interpreted as shown in Table 5.

Table 5: E-learning proficiency levels

\begin{tabular}{ll}
\hline Mean & Interpretation \\
\hline $1.0-2.6$ & Not proficient, needs a lot of work \\
$2.61-3.4$ & Not proficient, needs some work \\
$3.41-4.2$ & Proficient but needs a few improvements \\
$4.21-5$ & Proficient \\
\hline
\end{tabular}

Source: Ouma, et al. (2013)

Table 6: Teachers' Computer Capacity in Schools with Digital Literacy Programme Devices

\begin{tabular}{lll}
\hline Code & Operation & Mean \\
\hline D1 & I can rotate an image & 3.88 \\
D2 & I can create a new document using Microsoft Word & 4.12 \\
D3 & I can create a new document using Microsoft Excel & 4.04 \\
D4 & I can draw and label diagrams using computers & 2.96 \\
D5 & I can use PowerPoint to present my lesson & 3.80 \\
D6 & I can save contents to an external disk & 4.00 \\
D7 & I can animate using computers & 3.16 \\
D8 & I can use a browser such as Mozilla or Explorer to navigate the World Wide Web & 3.60 \\
D9 & I know how to send and receive email messages & 3.36 \\
D10 & I can print a document & 3.88 \\
Mean & & $\mathbf{3 . 6 8}$ \\
\hline
\end{tabular}

43 This work is licensed under a Creative Commons Attribution 4.0 International License 
Average mean scores for computer competency areas from D1 to D10 as displayed in table 5 were calculated based on a five-point Likert scale where 1 stood for Not at all, 2 for Not so well, 3 for Okay, 4 for Well, and 5 for Very well. It is shown that the DLP trained teachers were proficient in rotation of an image $\left(\mathrm{M}_{\mathrm{D} 1}=3.88>\mathrm{M}_{\mathrm{elr}}=3.41\right)$, creation of a new document using Microsoft Word $\left(\mathrm{M}_{\mathrm{D} 2}=4.12>\right.$ $\left.\mathrm{M}_{\mathrm{elr}}=3.14\right)$, creation of new documents using Microsoft Excel $\left(\mathrm{M}_{\mathrm{D} 3}=4.04>\mathrm{M}_{\mathrm{elr}}=3.14\right)$, use of PowerPoint to present lessons $\left(\mathrm{M}_{\mathrm{D} 5}=3.80>\mathrm{M}_{\mathrm{elr}}\right.$ $=3.41$ ), saving contents to an external disk (flash disk) $\left(\mathrm{M}_{\mathrm{D} 6}=4.00>\mathrm{M}_{\mathrm{el} \mathrm{r}}=3.14\right)$, using search engines such as Mozilla or Explorer to navigate the World Wide Web $\left(\mathrm{M}_{\mathrm{D} 8}=3.60>\mathrm{M}_{\mathrm{elr}}=3.41\right)$ and finally proficiency in printing documents $\left(\mathrm{M}_{\mathrm{elr}}=\right.$ $3.41>\mathrm{M}_{\mathrm{D} 10}=3.88$ ) using laptop computers. It was, however, noted that the DLP trained sample teachers could averagely draw and label diagrams using laptop computers $\left(\mathrm{M}_{\mathrm{elr}}=3.41>\mathrm{M}_{\mathrm{D} 4}=2.96\right)$, animate using laptop computers $\left(\mathrm{M}_{\mathrm{elr}}=3.41>\mathrm{M}_{\mathrm{D} 7}\right.$ $=3.16$ ), and lastly send and receive email messages $\left(\mathrm{M}_{\mathrm{elr}}=3.41>\mathrm{M}_{\mathrm{D} 9}=3.36\right)$.

\section{DISCUSSION}

The research was carried out in 56 sample schools in Homa Bay County to assess the level of computer integration in schools that had received DLP devices. 56 sample teachers who were teaching using laptop computers in these schools were the respondents. The findings showed that 31 (55.4\%) schools out of 56 sample schools which were the majority of schools that had received digital devices had not launched digital learning in their respective schools citing reasons such as inadequate computer skills amongst teachers, 11 (35.5\%). To prove this, the findings were in concurrence with other researches which also revealed that even though some schools were in possession of the DLP devices, teachers in such schools were found not to use them for fear of being replaced by technology and that their learners who were proficient in computer use would outsmart them in class (Kimuge, 2017; Okello-Obura \& Ssekitto, 2015; Sharples \& Moldies 2014). In another concurrence, Hernandez (2017) also agreed by saying that integrating ICT into education is grossly dependent on the teacher's computer skills to handle online tools.
The study connected the failure of DLP launch in schools to a lack of steady sources of power. The findings showed that $10(32.4 \%)$ sample schools received DLP devices ahead of power connections in their schools which contradicted the government's position that over $19,000(84.4 \%)$ schools had been connected to electricity by 2015 (Republic of Kenya, 2015). In contradiction, ICT Authority in Homa Bay County maintained that the 551 schools that had received DLP devices in Homa Bay County were connected to electricity (Kenya. ICTAL, 2016). Even though the study established that $63(74.8 \%)$ schools that were studied either had a functional power source or close-range transformers that the schools could easily tap electricity from, the study noted that a number of schools still had not been connected to any source of power.

The distribution of the digital devices to subcounties of Homa Bay was also not uniform. According to the statistics of this research under population and sample size estimation, Rachuonyo South was second to Homa Bay in terms of teacher population. But out of the 551 schools that had received DLP devices in Homa Bay County by 2016, Rachuonyo South Sub-County had only 48 (8.7\%) of its schools with DLP devices (Kenya. ICTAL, 2016). The ICT Authority in Homa Bay County argued in its report that only schools in subcounties that 'looked' ready for the integration of laptop computers were given first priority in the distribution of digital devices. The study found the argument lacking merit because 10 (32.4\%) schools out of the 56 sample schools with DLP devices had no functional power but were in possession of DLP devices. It was, therefore, not very clear to the study the kind of criteria used to distribute digital devices to different sub-counties.

The study established that the respondents had no adequate information on which particular organization(s) were responsible when breakages and malfunctions of the DLP devices took place in a school. This created fear in the use of such devices. To some extent, the study linked such failure to launch DLP in these schools to technophobia (Juma, 2001). Some respondents were of the opinion that they could not touch or train using DLP devices because like any other electronic device they were bound to have breakages and 
repairs. The findings revealed that 22 (39.3\%) respondents, who were the majority in schools with DLP devices, did not know where to repair faulty or broken DLP devices. Although the ICT Authority in Kenya spelled out that the distribution of the DLP devices was supposed to be done by some other organizations which were either Moi University or Jomo Kenya University of Science and Technology, this communication did not reach schools well and many respondents ended up being confused. It was, therefore, apparent that the respondents were unable to differentiate the roles of the Ministry of Education, ICT Authority, and the organizations that were supplying the devices to schools. It seemed that there were no guidelines provided by the government on the administration of DLP in Kenya. In support, Standard Team (2019) observed that a number of primary schools decried disconnect with experts charged with the maintenance of the programme. In such schools, teachers' laptops and tablets were rendered useless after the software ran out of date.

However, the study noted that ICT Authority in Homa Bay County was doing a commendable job by regularly organizing both physical and online training for teachers and headteachers (Kenya. ICT Authority, 2016). Despite this, the implementation of DLP needed a clear policy in procurement, distribution, and implementation. In support, the eLearning Foundation (2013) called for the need for an ICT policy document to streamline the implementation process.

When the general performance in all areas of laptop computer expertise was tested, it showed that sampled DLP-trained teachers were more ready for the integration of laptop computers in public primary schools in Kenya. This was based on the average mean (3.68) for all areas of computer skills that were observed against the set e-learning readiness scale of 3.41 (Aydin \& Tasci, 2005). The findings proved that although the duration of DLP training was short, it laid the foundation for practice (European Commission, 2011; Tilya, 2007).

And when interviews were conducted with sample teachers and head teachers on their capacity to handle and teach pupils using laptop computers, the findings revealed that $18(100 \%)$ respondents who were both teachers and head teachers contradicted results from questionnaires and observation checklist which found DLP trained teachers and teachers teaching with devices in schools ready for the launch of digital education. Revelation from one respondent who was interviewed noted that:

...My opinion in the introduction of teaching using technology is positive but I feel the government is bringing it in when good readiness is not yet put in place. I feel it was good to introduce it to learners but it is like the government is not having a good plan for its introduction... (Teacher, Rachuonyo South).

Respondents interviewed admitted not being capable of competently teaching using laptop computers citing duration of training as too short, unavailability of laptop computers in their schools for practice, lack of time for private computer training, and speedy launch of DLP without proper needs assessment. It was also noted from the interviews that many teachers were left out during DLP training for teachers, but still, it was evident that some of these teachers had received ICT training elsewhere. In addition, both male and female teachers were not discriminated against in DLP training (Bakr, 2011).

The findings also showed that ICT integration was active in $25(44.6 \%)$ schools out of the 56 sample schools that had received DLP devices. Contrary to the expectations of the government that DLP devices were to be used as tools for teaching and learning, the study noted that there were no specified times in most school timetables for teaching and learning using DLP devices. In support, Standard Team (2019) also noted that tablets were reduced to toys in schools. The pupils were offered tablets to play with as toys at no specified time (Wanzala, \& Nyamai, 2018). To confirm this one respondent during oral interviews said:

Not as ...It can be brought not as a ... the sole mechanism of delivering the content... but can be brought as a way of play things like that; they first of all embrace. Not available but I believe it will be availed. Yes. Personally am...am... content with it... am comfortable with it. So long as we have been trained. You know even the manual one we were trained. So when we are 
trained on how to handle the digital one then what is the big deal (Head teacher, Mbita).

Real teaching and learning were still being conducted manually by the use of textbooks. Examinations for these pupils were still being set and marked manually. There was no close supervision or distinct policies on digital learning in schools. In some schools, teachers utilized laptop computers only to learn how to prepare crucial learning documents such as entry of pupils' marks.

In connection to the phases of ICT training as observed by the European Commission (2001), the study observed that sampled teachers were offered several DLP training packages in 5 days. But in reality, DLP-trained teachers despite their high proficiency levels in computer skills were still struggling with the first phase of computer familiarization. It is like the Kenyan DLP training underrated this computer familiarization phase in its plan for teacher training which may call for further re-evaluation on what is good for the training of teachers in Kenya for DLP.

\section{CONCLUSION}

It was concluded that integration of technology in primary school education was a noble idea but needed not to be done hurriedly that left many learning institutions lagged behind others. However, despite the very many challenges, DLP was a great success for schools, teachers, and learners. For instance, learners from poor backgrounds had the opportunity to touch and manipulate digital devices for the first time in their lives. Remote primary schools had the opportunity to enjoy electric power from the national grid. Teachers on the other hand aggressively fought technophobia and used digital devices for teaching preparations besides the actual teaching in class using such devices. The study noted that the teething issues such as inconsistent start times for digital learning in different schools were a major threat in achieving the objectives of DLP especially on curriculum implementation in Kenya which should be uniform. It was recommended that the Government of Kenya should make a thorough audit of the whole programme and urgently address the shortages of key variables of DLP such as electric power, staffing, training of teachers for DLP, security of schools among other things.

\section{REFERENCES}

Aydin, C. H., \& Tasci, D. (2005). Measuring readiness for e-learning: Reflections from an emerging country. Educational Technology \& Society, 8 (4), 244-257.

Bakr, S. M. (2011). Attitudes of Egyptian teachers towards computers. Contemporary Educational Technology, 2 (4), 308-318.

Creswell, J. W. (2011). Research design. Qualitative, quantitative, and mixed methods approach ( ${ }^{\text {rd }}$ Ed.). Boston: Pearson Education, Inc.

e-Learning Foundation. (2013). Report into changes in numbers and quality of school owned PCs and laptop computers.

European Commission. (2001). Information and communication technology in European education systems. Brussels: Eurydice European Unit

European Commission. (2011). Key data on learning and innovation through ICT at school in Europe. Brussels: Education, Audio-visual and Culture Executive Agency.

Gay, L.R., \& Diehl, P.L. (1992). Research methods for business and management. New York: Macmillan.

Gilbert, O., Irene, D. J., \& James, S. (2020). Relationship between ICT usage for internal communication and principals' administrative quality in public secondary schools in Homa Bay County. International Journal of Academic Research in Business and Social Sciences, 10(3), 869-881.

Gökmen, Ö. F., Duman, İ., \& Akgün, Ö. E. (2018). Teachers' views about the use of tablet computers distributed in schools as part of the faith project. Malaysian Online Journal of Educational Technology, 6(2), 21-37.

Hennessy, S., Harrison, D., Ang'odi, E. K., Nemalefe, S., Naseem, A., \& Wamakote, L. 
(2010). Developing the use of information and communication technology to enhance teaching and learning in east African schools: Review of the literature. Eastern Africa: Centre for Commonwealth Education and Aga Khan University Institute for Educational Development.

Hernandez, R. M. (2017). Impact of ICT on education: Challenges and perspectives. A manuscript presented for publication, 5(1), 325347.

ICTAL (2016). Homa Bay Digital Literacy Report. Homa Bay County: ICT Authority

Juma, M. (2001). The establishment of a higher education open and distance learning knowledge base for decision makers in Kenya. Retrieved from UNESCO website: http://www.UNESCO.org/education/studyingab $\mathrm{road} / \mathrm{highlight/od/kb/kenya.doc.}$

Kimuge, S. (2017, June 22). Teachers hiding primary school tablets, official says. Daily Nation.

Lim, C.P., Zhao, Y., Tondeur, J., Chai, C. S., \& Tsai, C.C. (2013). Bridging the gap: Technology trends and use of technology in schools. Educational Technology and Society, 16 (2), 5968.

Lloyd, M. (2005). Towards a definition of the integration of ICT in the classroom. Proceedings of AARE '05 Education Research - Creative Dissent: Constructive Solutions, Parramatta, New South Wales. Retrieved from: https://eprints.qut.edu.au

McLoughlin, I. V. (2011). Computer architecture: an embedded approach. Retrieved from: http://www.lintech.org/comp-per/00intro.pdf

Mike, F. (2011). The Roles of information communication technologies in education. Ethiopian Journal of Education and Science, 6 (2).

MoE. (2006). National ICT strategy for Education and Training. Nairobi: Ministry of Education
Okello-Obura, C. \& Ssekitto, F. (2015). Web 2.0 technologies application in teaching and learning by Makerere University academic staff. Library Philosophy and Practice (e-journal), (1248).

Reddy, V., \& Majolica, S. (2002). Towards virtualization: Open and distance learning. India: Kogan Page

Republic of Kenya. (2015). Digital Literacy Program [press release].

Republic of Rwanda. (2015). ICT in education/ eleaning in Rwanda. A presentation by the minister of state in charge of pre-primary, primary and secondary education.

Sharples, T., \& Moldies, K. (2014). Ready or not, here ICT comes: A case study on e-readiness and governance in Kenya's laptop computers project (Unpublished masters dissertation).

Tilya, F. (2007). ICT in education in Tanzania. Lessons and experiences from IICD-supported projects.

Tolmie, A., Muijs, D., \& McAteer, E. (2011). Quantitative methods in educational and social research using SPSS. Berkshire. UK: Open University Press.

Wanzala, O., \& Nyamai, F. (2018). Big hurdles thwart Jubilee's laptops plan. https://nation.africa/kenya/news/Bighurdles-thwart-Jubilee-s-laptops-plan/10564676332-9w2jndz/index.html 